\title{
Mercury distribution in key tissues of fish (Liza aurata) inhabiting a contaminated estuary - implications for human and ecosystem health risk assessment
}

\author{
Cláudia Leopoldina Mieiro, ${ }^{* a b}$ Mário Pacheco, ${ }^{b}$ Maria Eduarda Pereira ${ }^{a}$ and Armando Costa Duarte ${ }^{a}$ \\ Received 2nd December 2008, Accepted 12th March 2009 \\ First published as an Advance Article on the web 24th March 2009 \\ DOI: $10.1039 / \mathrm{b} 821253 \mathrm{~h}$
}

This study brings a new viewpoint based on multiple-tissue analyses to form the basis for a predictive mode of mercury accumulation dynamics in fish body under field conditions. Total mercury $(\mathrm{T}-\mathrm{Hg}$ ) was determined in key tissues of Liza aurata captured along an estuarine contamination gradient, displaying the following hierarchy: kidney $>$ liver $>$ muscle $>$ brain $>$ gills $>$ blood. Brain was the tissue that better reflected the mercury contamination extent, closely followed by liver and muscle. Organic mercury $(\mathrm{O}-\mathrm{Hg})$ measured in muscle and liver represented more than $85 \%$ and less than $30 \%$ of the $\mathrm{T}-\mathrm{Hg}$, respectively. The lowest $\mathrm{O}-\mathrm{Hg}$ percentage was found in the most contaminated area, for both muscle and liver. Mercury distribution and accumulation patterns showed dependence on the specific tissue. The high mercury levels found in organs involved in vital physiological processes point out the risk to autochthonous fish fauna. Human risk associated to the ingestion of fish living in the surveyed areas cannot be excluded.

\section{Introduction}

Estuarine habitats are potentially impacted by many anthropogenic influences, being important sinks of pollutants ${ }^{1}$ where metals represent a particular threat for both aquatic wildlife and humans. Among metals of environmental concern, mercury has deserved increasing attention due to its ubiquity, persistence and toxicity. Mercury has high affinity for suspended particles, which conducts its removal from the water column and accumulation in sediments. Thus, sediments function as deposit and as source of mercury to the pore water and biota. ${ }^{2}$ It is also known that methylation processes mediated by bacteria occur in sediments, converting inorganic mercury into methylmercury, the most toxic form. Both methylmercury and inorganic mercury are present in the organisms associated to sulfhydryl groups, thereby disturbing almost any function where critical or non-protected proteins are involved. ${ }^{3}$

The direct and indirect coupling between ichthyofaunal communities and human impact on estuaries reinforces the choice of this taxonomic group as a biological indicator that can assist in the formulation of environmental and ecological quality objectives, and in the setting of quality standards. ${ }^{4}$ Fish is the main route of environmental exposure to mercury and, thus, the main source of methylmercury in human diets. ${ }^{5}$ Methylmercury concentrations in fish are approximately 1000 to 10000 times greater than in other food (such as cereals, vegetables, meats, eggs and milk), ${ }^{6}$ presenting a risk of negative impact on human health, affecting the central nervous (CNS), cardiovascular and immune systems. ${ }^{6,7}$ On the other hand, due to its wide

${ }^{a}$ CESAM and Departamento de Química, Universidade de Aveiro, Campus Universitário de Santiago, 3810-193 Aveiro, Portugal.E-mail: cmieiro@, ua.pt; Fax: +351234370084; Tel: +351234370360

${ }^{b}$ CESAM and Departamento de Biologia, Universidade de Aveiro, 3810193 Aveiro, Portugal distribution and trophic position, fish are particularly able to reflect aquatic contamination by metals, thus being desirable components of biomonitoring programs. Therefore, from the standpoint of both human and ecosystem health risk assessment, fish emerge as a suitable choice.

The prediction of the fate of metals with simple models is virtually impossible. Hence, according to Van der Oost et al., ${ }^{\mathbf{8}}$ bioaccumulation should be addressed including toxicokinetics, metabolism, biota-sediment accumulation factors and organspecific bioaccumulation. While considerable work has focused on mercury accumulation in fish liver and muscle, the most common body burdens, ${ }^{9,10}$ relatively little attention has been devoted to the distribution in other important target tissues. Moreover, the majority of available literature, though sporadically addressing other tissues, concerns laboratory approaches. ${ }^{11,12}$ The significance of fish laboratory exposures is often compromised by the use of environmentally unrealistic concentrations, as well as by artificial modes of exposure such as a single exposure route. Additionally, previous field studies didn't take into account an extensive range of tissues, and their main purpose was to assess the human risk through fish consumption. ${ }^{13,14}$ The field work carried out by Cizdziel et al. ${ }^{15}$ and MauryBrachet et al. ${ }^{16}$ constitute an exception, since a wide set of tissues was evaluated, but it concerned only freshwater species.

In the light of the previous statements, it is manifest that the whole-fish picture was not fully explored in marine species under realistic conditions, and further information is still needed concerning a wide and representative variety of key tissues. This integrated and multi-compartment approach is essential to predict mercury bioavailability to fish as well as for a meaningful risk assessment. In this perspective, the present study brings a new viewpoint in the distribution of total mercury in six tissues (gills, blood, brain, liver, kidney and muscle) evaluated in feral golden grey mullet (Liza aurata) captured along a mercury 
contaminated area (Laranjo Basin, Ria de Aveiro, Portugal). The study area was selected on the basis of an identified mercury gradient resulting from five decades of continuous discharges from a chlor-alkali plant. ${ }^{17}$ This confined mercury gradient and the absence of other important sources of contamination offer a unique opportunity for the assessment of mercury accumulation dynamics under natural conditions. Thus, the main objectives of this study were: (i) to investigate the tissue-specific total mercury loads in Liza aurata and their relation to abiotic concentrations (water, sediment and suspended particulate matter-SPM); (ii) to improve the knowledge on mercury uptake, distribution and retention, and select the tissue that better reflects the metal contamination degree; (iii) to evaluate the environmental risk to the autochthonous fish fauna; and (iv) to measure total mercury and methylmercury concentrations in the edible tissue in order to estimate the risk for human health resulting of the consumption of fish inhabiting the study area.

\section{Material and methods}

\subsection{Study area}

Ria de Aveiro is a lagoon adjacent to the Atlantic Ocean presenting an inner area (Laranjo Basin) (Fig. 1) which has persistently received mercury-containing effluents from a chlor-alkali plant since the 1950s until 1994. The discharges resulted in an accumulation of about $27 \times 10^{3} \mathrm{~kg}$ of mercury in the lagoon, mostly (about 74\%) associated to the sediment in the Laranjo Basin. ${ }^{17}$ Due to the basin's morphology, mercury deposition occurred mainly in the entrance of the basin, decreasing farther from the contamination source; and low mercury concentrations can be found throughout the Ria de Aveiro lagoon., ${ }^{2,18}$

The field campaign took place in March 2007 at three different locations chosen according to the distance to the mercury source.

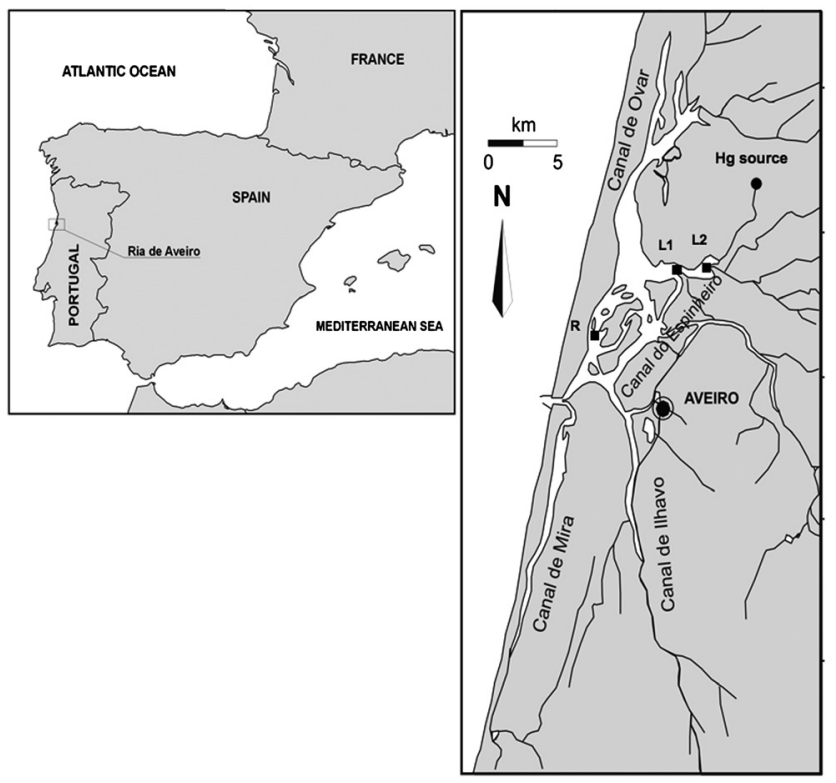

Fig. 1 Map of the sampling stations ( $\boldsymbol{\square})$ in the Ria de Aveiro (Portugal): reference $\left(\mathrm{R}-40^{\circ} 41^{\prime} 00^{\prime \prime} \mathrm{N}, 8^{\circ} 42^{\prime} 44^{\prime \prime} \mathrm{W}\right)$, moderately (L1$40^{\circ} 43^{\prime} 34.46^{\prime \prime} \mathrm{N}, 8^{\circ} 38^{\prime} 53.16^{\prime \prime} \mathrm{W}$ ) and highly contaminated (L2$40^{\circ} 43^{\prime} 28.98^{\prime \prime} \mathrm{N}, 8^{\circ} 37^{\prime} 35.80^{\prime \prime} \mathrm{W}$ ) areas.
Two sampling sites (L1 and L2) were chosen at Laranjo Basin, separated by a $2 \mathrm{~km}$ distance: L2 located closer to the mercury source and identified as a highly contaminated area and L1, downstream of L2, as a moderately contaminated. A reference area $(\mathrm{R})$ located in S. Jacinto was selected for comparison purposes due to its proximity to the lagoon entrance and the distance to the main polluting sources. ${ }^{19}$

\subsection{Sampling procedures}

Fifteen juvenile golden grey mullets (Liza aurata) from the samesize group, i.e. with a total length of $11.6 \pm 1.25 \mathrm{~cm}$ and wet weight (w wt) of $14.6 \pm 5.47 \mathrm{~g}$ (average \pm standard deviation), were collected at each sampling site during low tide using a beach-seine net named "chincha". Immediately after being caught, the fish were sacrificed according to ethical recommendations and blood, brain, kidney, liver, gills and muscle (lateral dorsal) were sampled and kept cold. Blood was collected from the posterior cardinal vein by using heparinised Pasteur pipettes.

At the laboratory, tissue samples were freeze-dried, homogenized, weighted for mercury fresh weight calculations, and total $(\mathrm{T}-\mathrm{Hg})$ and organic $(\mathrm{O}-\mathrm{Hg})$ mercury (only for muscle and liver) analyses were performed.

Water physico-chemical parameters such as $\mathrm{pH}$ (WTW-pH 330i), dissolved oxygen (WTW-oxi 330i), temperature and salinity were measured at sub-surface level in low and high tide conditions. Turbidity was measured using a $20 \mathrm{~cm}$ black and white Secchi disc, and water column depth was also evaluated. Sub-surface water samples were collected in acid-washed plastic bottles (one sample per site and tide conditions) and kept cold during transportation to the laboratory, where they were immediately filtered through pre-weighed $0.45 \mu \mathrm{m}$ Millipore cellulose acetate membrane filters, acidified with "mercury-free" $\mathrm{HNO}_{3}$ to $\mathrm{pH}<2$ and stored at $4{ }^{\circ} \mathrm{C}$ until analysis. Filters were reweighed after drying overnight at $60{ }^{\circ} \mathrm{C}$ and stored for determination of mercury in suspended particulate matter (SPM-Hg). Five replicates of surface sediments were taken in each sampled area. At the laboratory, sediment samples were freeze-dried, homogenized and sieved through a $1 \mathrm{~mm}$ sieve and stored for mercury determination.

\subsection{Mercury analysis}

Reactive $(\mathrm{R}-\mathrm{Hg})$ and total dissolved mercury (Dis- $\mathrm{Hg}$ ) in water were analysed by cold-vapour atomic fluorescence spectrometry (CV-AFS) with a PSA model Merlin 10.023 equipped with a detector PSA model 10.003 using $\mathrm{SnCl}_{2}$ reduction. For Dis- $\mathrm{Hg}$ analysis, $50 \mathrm{~mL}$ of each sample was oxidized with $500 \mu \mathrm{L}$ of a saturated solution of potassium persulfate and by irradiation with a UV lamp (1000 W) for $30 \mathrm{~min}$; following irradiation, the excess of oxidant was reduced with $37.5 \mathrm{~mL}$ of hydroxylamine solution $12 \%(\mathrm{w} / \mathrm{v}) .{ }^{20}$ For the determination in SPM (SPM-Hg), the same equipment was used after digestion of the filters with $\mathrm{HNO}_{3} 4 \mathrm{~mol} \mathrm{~L}^{-1} \cdot{ }^{17}$

Sediments (Sed-Hg) and L. aurata tissues samples were analysed for $\mathrm{T}-\mathrm{Hg}$ by atomic absorption spectrometry (AAS) with thermal decomposition and gold amalgamation, using an Advanced Mercury Analyser (AMA) LECO 254. ${ }^{21}$ The accuracy and precision of the analytical methodology for total mercury 
determinations were assessed by replicate analysis of certified reference materials (CRM), namely MESS-3 and PACS-2 (marine sediments) for sediments and TORT-2 (lobster hepatopancreas) for biological samples. The precision of the method was always better than $9 \%(n>3)$, with a recovery efficiency between $92-103 \%$.

Organic mercury $(\mathrm{O}-\mathrm{Hg})$ determination was performed according to Válega et al., ${ }^{22}$ through digestion of the sample with a mixture of $18 \% \mathrm{KBr}$ in $5 \% \mathrm{H}_{2} \mathrm{SO}_{4}$, followed by extraction into toluene. Extractions were performed in duplicates and the aqueous fraction resulting from the addition of a $\mathrm{Na}_{2} \mathrm{~S}_{2} \mathrm{O}_{3}$ solution was analysed using an AMA LECO 254 set up for total mercury. Since this method requires a high sample amount $(0.05-$ $0.2 \mathrm{~g}$ ), it was only possible to perform the analyses in muscle and liver samples. For the same reason, liver composite samples of three fish were prepared. Due to the lack of sufficient sample, the analysis was not performed in the fish from $\mathrm{R}$. To validate the $\mathrm{O}-$ $\mathrm{Hg}$ analyses, reference material TORT-2 was used. The precision of the method ranged between 0 and $5.9 \%$, with a median extraction efficiency of $101.3 \%$.

\subsection{Statistical analysis}

Data analysis followed standard statistical procedures. ${ }^{23}$ Data were tested for goodness of fit to a normal distribution, and requirements of homogeneity of variances were also determined. Analysis of variance (ANOVA) on ranks were performed followed by all pairwise multiple comparison procedures (Tukey test). Whenever the assumptions for parametric statistics failed, the non parametric correspondent test (Kruskall Wallis) was performed, followed by the non parametric all pairwise multiple comparison procedure (Dunn's test). The Spearman rank correlation factor $(r)$ was determined for the total mercury concentration between the different tissues. Differences between means were considered significant at $p<0.05$.

\section{Results}

\subsection{Environment characterization}

Physico-chemical parameters of the water are summarized in Table 1. In general, the three sampling stations were similar regarding environmental characterization with the exception of salinity during low tide, which ranged from 13 in L2 to 34 in the $\mathrm{R}$ station. SPM in low tide also exhibited differences, i.e. L2 levels were 2.2 and 1.3 times higher in relation to $\mathrm{R}$ and $\mathrm{L} 1$, respectively. Parameters such as temperature, $\mathrm{pH}$, dissolved oxygen, water depth and turbidity were in the same range.

\subsection{Mercury in water (dissolved and in SPM) and in sediment}

Mercury concentrations in the water column were, in general, low in the three sampling stations (Table 2). At high tide, only SPM-Hg showed higher values in the Laranjo area (L1) in relation to $\mathrm{R}$. In contrast, during low tide conditions, $\mathrm{R}-\mathrm{Hg}$ concentrations were similar in all the stations, while Dis- $\mathrm{Hg}$ concentrations doubled in L2 compared to R and L1. The SPM$\mathrm{Hg}$ concentration was almost ten times higher in $\mathrm{L} 2$ than in $\mathrm{R}$. Relevant differences between tides at each sampling station were observed mainly for $\mathrm{T}-\mathrm{Hg}$, showing clearly higher levels in low tide at $\mathrm{L} 2$ and the opposite at $\mathrm{R}$.

Total mercury concentrations in sediments (Sed- $\mathrm{Hg}$ ) increased 8 times from the reference station (R) to L1 and 85 times from L1 to L2, displaying the environmental contamination gradient (Table 2). L2 presented an increment of 680 times in relation to R.

\subsection{Mercury accumulation in fish tissues}

$\mathrm{T}-\mathrm{Hg}$ concentrations, either in $\mathrm{R}$ or the contaminated stations (L1 and L2), varied according to the tissue in the following manner: kidney $>$ liver $>$ muscle $>$ brain $>$ gills $>$ blood (Fig. 2). Globally, $\mathrm{T}-\mathrm{Hg}$ values ranged from 0.008 (blood at $\mathrm{R}$ ) to 1.19 (kidney at L2) $\mathrm{mg} \mathrm{kg}^{-1} \mathrm{w}$ wt.

Table 2 Concentrations of reactive mercury $(\mathrm{R}-\mathrm{Hg})$, total dissolved mercury (Dis- $\mathrm{Hg})\left(\mathrm{ng} \mathrm{L}^{-1}\right)$, total mercury in suspended particulate matter (SPM-Hg) $\left(\mathrm{mg} \mathrm{kg}^{-1}\right)$ in water, and total mercury in sediments (Sed-Hg) ( $\mathrm{mg} \mathrm{kg}^{-1}$ dry weight (d wt)) (average \pm standard deviation) at each sampling station at Ria de Aveiro: reference (R), moderately (L1) and highly mercury contaminated (L2) areas. ${ }^{a}$

\begin{tabular}{|c|c|c|c|c|c|}
\hline \multirow[b]{2}{*}{$\begin{array}{l}\text { Sampling } \\
\text { station }\end{array}$} & \multirow[b]{2}{*}{ Tide } & \multicolumn{3}{|l|}{ Water } & \multirow{2}{*}{$\begin{array}{l}\text { Sediment } \\
\text { Sed-Hg/ } \\
\mathrm{mg} \mathrm{kg}^{-1} \mathrm{~d} w\end{array}$} \\
\hline & & $\begin{array}{l}\mathrm{R}-\mathrm{Hg} / \\
\mathrm{ng} \mathrm{L}^{-1}\end{array}$ & $\begin{array}{l}\text { Dis-Hg/ } \\
\text { ng L L }^{-1}\end{array}$ & $\begin{array}{l}\text { SPM-Hg/ } \\
\mathrm{mg} \mathrm{kg}^{-1}\end{array}$ & \\
\hline \multirow[t]{2}{*}{$\mathrm{R}$} & High & $5.8 \pm 1.0$ & $19 \pm 4.5$ & $0.6 \pm 0.08$ & \multirow{2}{*}{$0.01 \pm 0.001$} \\
\hline & Low & $4.4 \pm 1.6$ & $10.3 \pm 1.1$ & $0.84 \pm 0.12$ & \\
\hline \multirow[t]{2}{*}{ L1 } & High & $3.0 \pm 1.4$ & $8.3 \pm 0.64$ & $1.2 \pm 0.72$ & \multirow[t]{2}{*}{$0.08 \pm 0.006$} \\
\hline & Low & $2.7 \pm 0.75$ & $10.6 \pm 0.91$ & $1.60 \pm 0.71$ & \\
\hline \multirow[t]{2}{*}{ L2 } & High & $3.0 \pm 0.64$ & $10.2 \pm 1.2$ & m.v. & \multirow[t]{2}{*}{$6.8 \pm 0.16$} \\
\hline & Low & $4.9 \pm 1.8$ & $20.8 \pm 2.4$ & $8.0 \pm 0.61$ & \\
\hline
\end{tabular}

Table 1 Hydrological characteristics of reference (R), moderately (L1) and highly mercury contaminated (L2) areas at Ria de Aveiro: water temperature (T), dissolved oxygen (DO), $\mathrm{pH}$, salinity, suspended particulate matter (SPM), turbidity and water depth. ${ }^{a}$

\begin{tabular}{|c|c|c|c|c|c|c|c|c|}
\hline Sampling station & Tide & $T /{ }^{\circ} \mathrm{C}$ & $\mathrm{DO} / \mathrm{mg} \mathrm{L}^{-1}$ & $\mathrm{pH}$ & Salinity & $\mathrm{SPM} / \mathrm{mg} \mathrm{L}^{-1}$ & Turbidity/m & Depth/m \\
\hline \multirow[t]{2}{*}{$\mathrm{R}$} & High & 16.4 & 10.8 & 8.4 & 34 & 45.1 & 1.2 & 5.4 \\
\hline & Low & 15.3 & 10.9 & 8.4 & 34 & 31.7 & 0.5 & 1.6 \\
\hline L1 & Low & 15.0 & 10.8 & 8.1 & 15 & 53.2 & 0.5 & 2.8 \\
\hline \multirow[t]{2}{*}{ L2 } & High & 12.5 & 8.7 & 8.3 & 32 & m.v. & 1.2 & 2.3 \\
\hline & Low & 12.2 & 8.9 & 7.8 & 13 & 70.0 & 0.3 & 1.0 \\
\hline
\end{tabular}

${ }^{a}$ m.V.-missed value. 


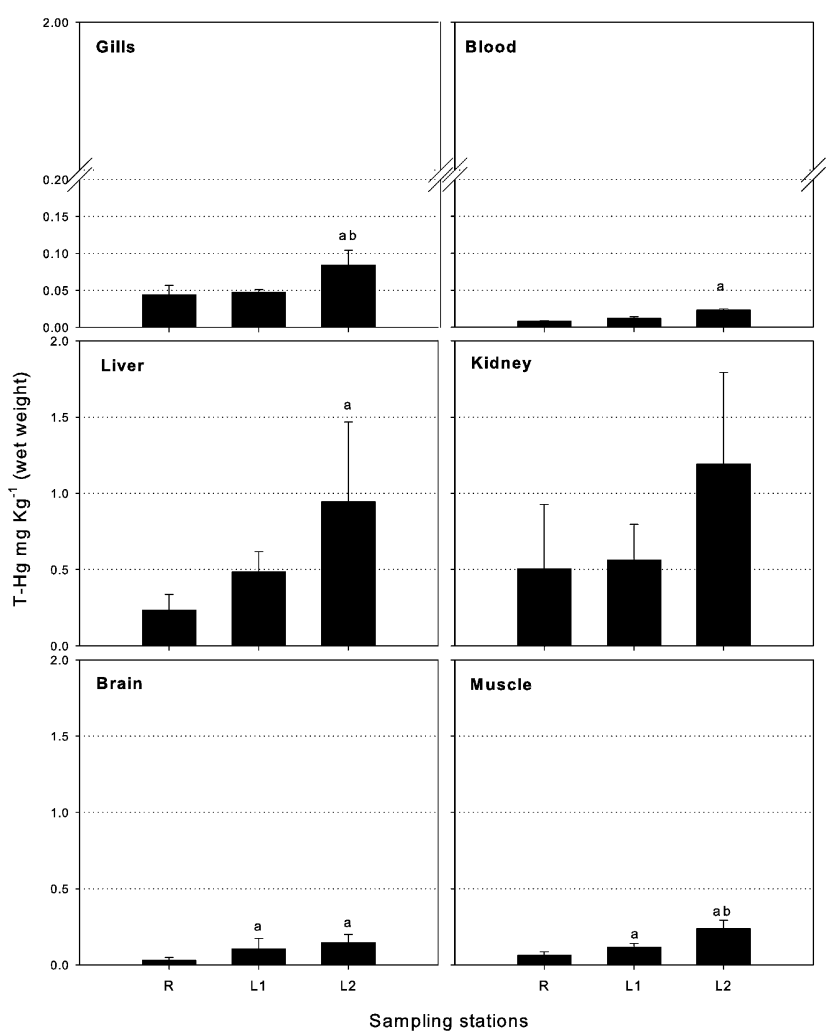

Fig. 2 Total mercury (T-Hg) average concentration $\left(\mathrm{mg} \mathrm{kg}^{-1} \mathrm{w} w \mathrm{w}\right)$ in each sampling station at Ria de Aveiro: reference (R), moderately (L1) and highly mercury contaminated (L2) areas. The letters denote statistically significant differences $(p<0.05)$ : (a) versus $\mathrm{R}$ and (b) versus $\mathrm{L} 1$. Error bars represent the standard deviation.

The inter-station statistical comparisons carried out for each individual tissue demonstrated that only brain and muscle displayed significantly higher $\mathrm{T}-\mathrm{Hg}$ levels in L1. Though not statistically significant, clearly higher $\mathrm{T}-\mathrm{Hg}$ values were observed in liver (2 times) comparing L1 with R. On the other hand, in L2 all the tissues, with the exception of kidney, showed significant differences to $\mathrm{R}$. The brain was the tissue that revealed the greater $\mathrm{T}-\mathrm{Hg}$ increase, followed by the liver, when comparing L2 with $\mathrm{R}$. Thus, when the $\mathrm{L} 2$ data were analysed in terms of $\mathrm{T}-\mathrm{Hg}$ increment degree in relation to $\mathrm{R}$, the tissues appeared ordered as follows: brain $(4.8 \times)>$ liver $(4.0 \times)>$ muscle $(3.8 \times)>$ blood $(2.8 \times)>$ kidney $(2.4 \times)>$ gills $(2.0 \times)$. Despite the lower increase magnitude, the same tissue ordination was observed in L1.

Statistically significant increments from L1 to L2 were only verified for gills and muscle (1.8 and 2 times, respectively).

Tissue-to-tissue $\mathrm{T}-\mathrm{Hg}$ ratios were calculated for the combination of all the assessed tissues (Table 3 ). The highest values were determined for tissue/blood ratios, being the maximum value found for kidney/blood, followed by the liver/blood ratio. Comparing each ratio in the three sampling stations, no statistically significant differences were found.

The Spearman rank correlation ( $r$ ) analysis revealed significant positive correlations between $\mathrm{T}-\mathrm{Hg}$ in muscle and in all the other tissues $(r=0.565, r=0.692, r=0.947, r=0.555$ and $r=0.807$ for gills, blood, liver, kidney and brain, respectively). Beside the mentioned correlation with muscle, $\mathrm{T}-\mathrm{Hg}$ in blood was also positively correlated with gills, liver and brain $(r=0.580, r=$ 0.573 and $r=0.748$, respectively). In addition, significant correlations were found between $\mathrm{T}-\mathrm{Hg}$ in liver and brain $(r=$ $0.745)$, as well as between gills and kidney $(r=0.621)$.

The determination of $\mathrm{O}-\mathrm{Hg}$ revealed high percentage values $(>85 \%)$ in muscle with a concentration range (absolute values) of $0.065-0.20 \mathrm{mg} \mathrm{kg}^{-1} \mathrm{w}$ wt, whilst hepatic $\mathrm{O}-\mathrm{Hg}$ was lower than $30 \%$ with a concentration range of $0.16-0.25 \mathrm{mg} \mathrm{kg}^{-1}$ (Table 4). The lowest percentage of $\mathrm{O}-\mathrm{Hg}$ was found in the most contaminated station (L2), both for muscle and liver. For muscle, significant differences $(p<0.05)$ were found in $\mathrm{O}-\mathrm{Hg}$ between $\mathrm{L} 2$ and $\mathrm{R}$ and between the two contaminated stations (L2 and L1). For liver, no significant difference in $\mathrm{O}-\mathrm{Hg}$ was found between L1 and L2 (comparisons with R are not feasible). A positive correlation was found between $\mathrm{T}-\mathrm{Hg}$ and $\mathrm{O}-\mathrm{Hg}$ in muscle $(r=$ $0.987 ; p<0.05)$.

Table 3 Inter-tissue ratios (average \pm standard deviation) for the three sampling stations at Ria de Aveiro: reference (R), moderately (L1) and highly mercury contaminated (L2) areas

\begin{tabular}{|c|c|c|c|c|c|c|c|}
\hline & Sampling station & \multicolumn{6}{|c|}{ Inter-tissue ratio } \\
\hline & L1 & - & $0.12 \pm 0.03$ & $4.02 \pm 0.36$ & $5.5 \pm 1.2$ & $0.4 \pm 0.09$ & $0.51 \pm 0.64$ \\
\hline & L2 & - & $0.10 \pm 0.04$ & $3.3 \pm 2.02$ & $3.3 \pm 3.0$ & $0.40 \pm 0.09$ & $0.70 \pm 0.30$ \\
\hline \multirow[t]{2}{*}{ Tissue/blood } & $\mathrm{R}$ & $7.5 \pm 2.5$ & - & $27 \pm 11.0$ & $65 \pm 0.42$ & $5.0 \pm 1.3$ & $4.4 \pm 2.1$ \\
\hline & L1 & $8.5 \pm 3.2$ & - & $32 \pm 13$ & $32 \pm 0.23$ & $4.0 \pm 0.90$ & $9.5 \pm 7.5$ \\
\hline & $\mathrm{L} 1$ & $0.25 \pm 0.021$ & $0.029 \pm 0.083$ & - & $1.0 \pm 0.24$ & $0.097 \pm 0.029$ & $0.12 \pm 0.18$ \\
\hline & L2 & $0.27 \pm 0.094$ & $0.027 \pm 0.012$ & - & $1.2 \pm 0.45$ & $0.11 \pm 0.047$ & $0.18 \pm 0.095$ \\
\hline \multirow[t]{3}{*}{ Tissue/kidney } & $\mathrm{R}$ & $0.28 \pm 0.27$ & $0.033 \pm 0.029$ & $0.60 \pm 0.9$ & - & $0.51 \pm 0.42$ & $0.17 \pm 0.13$ \\
\hline & L1 & $0.24 \pm 0.07$ & $0.028 \pm 0.014$ & $0.98 \pm 0.202$ & - & $0.56 \pm 0.23$ & $0.26 \pm 0.22$ \\
\hline & L2 & $0.25 \pm 0.12$ & $0.023 \pm 0.013$ & $0.87 \pm 0.31$ & - & $1.2 \pm 0.82$ & $0.18 \pm 0.13$ \\
\hline \multirow[t]{2}{*}{ Tissue/gills } & $\mathrm{R}$ & $1.6 \pm 0.85$ & $0.2 \pm 0.05$ & $6.1 \pm 3.9$ & $10.4 \pm 8.1$ & - & $0.70 \pm 0.5$ \\
\hline & L1 & $2.5 \pm 0.52$ & $0.26 \pm 0.051$ & $10 \pm 3.0$ & $12.0 \pm 5.1$ & - & $1.4 \pm 1.2$ \\
\hline
\end{tabular}


Table 4 Total $(\mathrm{T}-\mathrm{Hg})$ and organic mercury $(\mathrm{O}-\mathrm{Hg})$ (average \pm standard deviation) concentrations $\left(\mathrm{mg} \mathrm{kg}^{-1} \mathrm{~d} \mathrm{wt}\right)$ and percentage of $\mathrm{O}-\mathrm{Hg}$ relative to $\mathrm{T}-\mathrm{Hg}$ in muscle and liver of L. aurata at each sampling station at Ria de Aveiro: reference (R), moderately (L1) and highly mercury contaminated (L2) areas. The letters denote statistically significant differences ( $p$ $<0.05$ ): (a) versus $\mathrm{R}$ and (b) versus $\mathrm{L} 1$. $\mathrm{O}-\mathrm{Hg} \%$ was calculated as the average of individual values of $\mathrm{O}-\mathrm{Hg} / \mathrm{T}-\mathrm{Hg} .{ }^{a}$

\begin{tabular}{lllll}
\hline $\begin{array}{l}\text { Sampling } \\
\text { station }\end{array}$ & Tissue & $\begin{array}{l}\mathrm{T}-\mathrm{Hg} / \mathrm{mg} \\
\mathrm{Kg}^{-1}\end{array}$ & $\begin{array}{l}\mathrm{O}-\mathrm{Hg} / \mathrm{mg} \\
\mathrm{Kg}^{-1}\end{array}$ & $\mathrm{O}-\mathrm{Hg} \%$ \\
\hline $\mathrm{R}$ & Muscle & $0.063 \pm 0.023$ & $0.07 \pm 0.02$ & $94.0 \pm 0.034$ \\
& Liver & $0.23 \pm 0.10$ & n.d. & n.d. \\
L1 & Muscle & $0.12 \pm 0.023^{\mathrm{a}}$ & $0.11 \pm 0.027$ & $97.0 \pm 0.058$ \\
& Liver & $0.51 \pm 0.11$ & $0.16 \pm 0.060$ & $30.0 \pm 0.051$ \\
L2 & Muscle & $0.24 \pm 0.055^{\mathrm{a}, \mathrm{b}}$ & $0.20 \pm 0.042^{\mathrm{a}, \mathrm{b}}$ & $85.0 \pm 0.082^{\mathrm{b}}$ \\
& Liver & $1.1 \pm 0.46^{\mathrm{a}}$ & $0.25 \pm 0.025$ & $24.0 \pm 0.077$
\end{tabular}

${ }^{a}$ n.d. - not determined.

\section{Discussion}

Mercury, as a non-essential element, is not expected to have its uptake/elimination actively regulated and subsequently its tissue concentrations can vary in a wide range, reflecting exposure to environmental levels and feeding behaviour. ${ }^{24}$ Hence, mercury body burdens in bioindicator species provide sensitive indications of aquatic pollution as well as of the potential impact on organism health. ${ }^{25}$ However, the metal distribution within the body depends on both the fish species and the metal's properties. ${ }^{26}$ Additionally, biotopes' physico-chemical characteristics and the dominant uptake route are important factors to determine the bioavailability and accumulation patterns. As mentioned in the literature, fish tissues have high mercury bioaccumulation capacity for both organic and inorganic forms; ${ }^{27}$ moreover, the mercury accumulation in different fish tissues is, to a large extent, dependent on their physiological role and regulatory ability. Therefore, in order to have a full insight of accumulation/detoxification mechanisms, several tissues/organs should be addressed.

The selection of key tissues/organs in the present study was carried out on the basis of their structural and functional properties, and subsequent association with the main processes that determine the mercury kinetics in fish body uptake, distribution, biotransformation, storage, and depuration/excretion. Gills, due to their wide surface area and continuous contact with the external medium, are considered the main route for uptake of mercury present in aqueous phase. ${ }^{28}$ In addition, their role in bioconcentration and excretion of toxicants can not be overlooked. Blood was selected as it is the vehicle for mercury distribution and can reflect current body burdens. ${ }^{29}$ Kidney and liver, besides their central role in basic physiology, are the main target organs, since they are actively involved in the metabolism of heavy metals, ${ }^{30}$ acting as detoxification and storage organs. ${ }^{31}$ Beyond its neurological functions essential for survival, brain is of interest because it is a target organ for methylmercury, which is able to react directly with important receptors. ${ }^{11}$ Skeletal muscle is essential in mercury accumulation assessment as it constitutes more than $60 \%$ of the fish's body mass and a significant amount of tissue can be used for analytical purposes. Furthermore, it is well known that mercury accumulates in muscle mainly in the methylated form, ${ }^{13,32}$ which is highly relevant regarding biomagnification along food chains and also the risk to human health.

\subsection{Relationships between environmental and tissue-specific mercury loads}

The physico-chemical environmental parameters were similar along the three sampling stations and, thus, do not affect determinately either the mercury bioavailability or the fish condition. Nonetheless, an exception should be made for the SPM levels, which were found to be higher in the Laranjo stations, namely at L2 in low tide (around 2 times the R levels). This difference is probably affecting the mercury bioavailability to fish, as discussed below.

Analysing the mercury levels in the different environmental compartments along the surveyed area, it is pertinent to stress that both Dis- $\mathrm{Hg}$ and $\mathrm{R}-\mathrm{Hg}$ were not regularly higher at Laranjo stations ( $\mathrm{L} 1$ and $\mathrm{L} 2$ ) in relation to $\mathrm{R}$. The importance of ascertaining the $\mathrm{R}-\mathrm{Hg}$ results from the fact that it is an easily reducible mercury species, representing the pool of mercury in the dissolved fraction that is bioavailable for the marine food web. ${ }^{33,34}$ Nevertheless, no clear differences in this mercury source are perceptible among sampling areas.

Contrarily, mercury in the sediment revealed great increments at the Laranjo stations relative to $\mathrm{R}$ (e.g. 680 times from $\mathrm{R}$ to L2). In the same way, SPM-Hg showed an increasing pattern towards the metal source. Considering the previously mentioned SPM increase in L2, the mercury bioavailability rise through this fraction can be estimated at around 21 times, i.e. 9.5 (for SPM$\mathrm{Hg}) \times 2.2($ for $\mathrm{SPM})=21$.

The hierarchy of the assessed tissues on the basis of the $\mathrm{T}-\mathrm{Hg}$ was kidney $>$ liver $>$ muscle $>$ brain $>$ gills $>$ blood. The few available field studies concerning the determination of mercury in different fish tissues provide heterogeneous accumulation patterns depending on the species. Maury-Brachet et al. ${ }^{16}$ found the highest $\mathrm{T}-\mathrm{Hg}$ either in kidney or in liver depending on the species, while muscle and gills presented substantially lower levels. In another study, ${ }^{15}$ a larger set of tissues was analysed displaying the order liver $>$ muscle $>$ brain $>$ gill $>$ blood, which completely agrees with our results found for L. aurata. Overall, the present results are consistent with the dominant idea proclaimed in the literature that liver and kidney are typically important organs for metal accumulation and storage in fish, presenting the highest mercury loads.

Comparing the tissue-specific $\mathrm{T}-\mathrm{Hg}$ between the sampling stations, it is noteworthy that all the assessed tissues, with the exception of kidney, were able to signal the mercury contamination at L2. On the other hand, only brain and muscle showed the ability to reflect the moderate contamination status occurring at L1. The absence of statistically significant increases in kidney was related to high inter-individual variance, probably a consequence of the limited amount of tissue available for chemical analysis.

According to Spry and Wiener, ${ }^{35}$ concentrations higher than 5 $\mu \mathrm{g}^{-1}$ of $\mathrm{T}-\mathrm{Hg}$ in brain and muscle are generally needed to exhibit symptoms of toxicity in fish. The levels measured in these tissues in L. aurata, though significantly elevated, are below that limit. 
An attempt to select the tissue that better reflects the mercury contamination extent should consider the following aspects: (1) the adoption of a tissue with high mercury loads may increase the assessment efficacy and minimize problems associated with the detection limits of the analytical methods; (2) a high increasing rate, measured in relation to reference conditions, improves the discriminatory power of a given tissue; (3) the capacity to distinguish low to high environmental mercury levels expands its applicability to different contamination scenarios. In view of point 1 , the liver appears as the best candidate followed by the muscle, since the usefulness of kidney seems to be compromised by the absence of statistically significant differences between $\mathrm{R}$ and L1 or L2 levels. Keeping in view the increments in environmental mercury levels from $\mathrm{R}$ to L2, namely in sediment (680 times) and SPM (9.5 times), and owing to the point 2, the brain would be the first choice ( 4.8 times increment), followed by the liver and muscle (4 and 3.8 times increment, respectively). Liver and kidney displayed the higher $\mathrm{T}-\mathrm{Hg}$ basal levels in $\mathrm{R}$; even so, liver demonstrated the ability to elevate $\mathrm{T}-\mathrm{Hg}$ almost as distinctively as the brain. In view of point 3 , brain and muscle appear as appropriate tissues, since both were able to signal mercury contamination at L1 and L2. Moreover, muscle was capable to distinguish between these two sites. Hence, a selection based on the joint analysis of the three criteria points out the brain as the most suitable tissue, closely followed by liver and muscle (brain $>$ liver $\approx$ muscle).

Though gills and blood displayed less mercury loads, they can be particularly recommendable for species with high mobility or in migratory stages, since they usually reflect current exposures while more quiescent tissues/organs with high storage propensity can reflect past exposure and, thus, increase the risk of misinterpretations.

The lowest percentage of $\mathrm{O}-\mathrm{Hg}$ was found in the most contaminated area (L2), for both muscle and liver. Similar results were previously reported ${ }^{36,37}$ and described as the "mercury accumulation paradox", being associated to the induction of mer-encoded enzymes responsible for the degradation of organic mercury. ${ }^{38}$ The induction of these enzymes is proportional to the mercury in the environment; high levels induced the mer-encoded system that promotes the demethylation of mercury, leading to low $\mathrm{O}-\mathrm{Hg}$ accumulation rates in biota. ${ }^{38}$

\subsection{Mercury accumulation dynamics}

In this point, the results are discussed with the purpose to form the basis for a predictive mode of mercury accumulation dynamics, mainly on account of $\mathrm{T}-\mathrm{Hg}$ inter-tissue ratios and correlations. The $\mathrm{T}-\mathrm{Hg}$ determination in the selected tissues compared to skeletal muscle (considered as the reference tissue for biomagnification effects) has been used to study the uptake, retention, and elimination of this metal in fish. ${ }^{15}$ Data from the literature indicate that when $\mathrm{T}-\mathrm{Hg}$ in fish muscle is relatively low (less than $0.5 \mathrm{mg} \mathrm{kg}^{-1} \mathrm{w} \mathrm{wt}$ ), the corresponding levels in the liver are lower than in the muscle. ${ }^{39}$ Considering that the current $\mathrm{T}-$ $\mathrm{Hg}$ in $L$. aurata muscle is of that magnitude $\left(<0.24 \mathrm{mg} \mathrm{kg}^{-1} \mathrm{w}\right.$ wt), lower levels would be expected for the liver. However, the liver displayed a $\mathrm{T}-\mathrm{Hg}$ around 4 times higher than the muscle $\left(<1.1 \mathrm{mg} \mathrm{kg}^{-1} \mathrm{w} \mathrm{wt}\right)$, corresponding to high liver/muscle ratios, which constitutes an apparent divergence with the statements of
Goldstein et al. ${ }^{39}$ (1996). In our opinion, this does not represent a disagreement with the functional explanations presented by Goldstein et al. ${ }^{39}$ but a need to redefine the point where this ratio is reversed: Goldstein et al. ${ }^{39}$ set that limit at $1 \mu \mathrm{g} \mathrm{g}^{-1}$ and the present results point to a four times lower level.

The occurrence of high liver/muscle ratios was previously reported in other fish species environmentally exposed. ${ }^{40,41}$ This fact, allied with the possibility of a reversion of the ratio to values $<1$, can be regarded as evidence that the liver has a central function in mercury accumulation, playing a buffering role, i.e. after liver retention capacity exhaustion, the mercury is able to bypass to muscle and, consequently, its accumulation in muscle starts increasing. Furthermore, the same type of action can be stated in relation with the other studied tissues (with the exception of kidney) seeing that the respective liver/tissue ratios were also $>1$.

The explanation presented by Henny et al. ${ }^{42}$ for the occurrence of high liver/muscle ratios is that as methylmercury exposure increases, the percentage of inorganic mercury in the liver increases, indicating greater hepatic demethylation. Subsequent binding and immobilization of inorganic mercury to metallothioneins, preferentially produced in the liver,$^{43}$ could result in augmented liver concentrations relative to muscle. ${ }^{15}$ This theory is supported by current mercury speciation analyses, showing a considerable prevalence of inorganic mercury $(70-76 \%$ of the total) in the liver, in contrast with muscle where organic mercury was the dominant form ( $85-97 \%$ of the total).

Taking into account that liver/kidney ratios were close to 1 (from 0.6 in R to 0.98 in L1) and all the kidney/tissue ratios were largely greater than 1 , the buffering role attributed to the liver should also be attributed to the kidney. Furthermore, in view of the feeding behaviour of $L$. aurata, the present results are in agreement with Maury-Brachet et al. ${ }^{16}$ who stated that high liver-kidney/muscle ratios are typically found in benthivorous fish species.

Most of the available data on tissue-to-tissue relations has been focused on tissue/muscle ratios, mainly because it is closely associated with the risk of human contamination via fish consumption. ${ }^{16}$ However, the computation of all the possible tissue-to-tissue relations can provide new information on mercury inter-tissues or tissue-blood exchange.

Data from the literature indicates that mercury uptake from food is the predominant accumulation pathway. ${ }^{44,45}$ However, in the present study, the importance of direct uptake via gills was ascertained. Furthermore, the relevance of aqueous uptake via gills on mercury toxicity was demonstrated in a previous study with $L$. aurata caged in Laranjo Basin, as the dietary uptake was almost completely restricted by caging. ${ }^{46}$ On the other hand, gills are between the venous and arterial circulation, receiving nearly all of the cardiac output and, thus, are predisposed to accumulate chemicals taken up by other exposure routes. In this context, the present data showed that gills/tissue ratios reach the maximum for blood and the minimum for liver, which can be an indication of a low relocation of mercury stored in the liver. The gills aptitude to maintain a high $\mathrm{T}-\mathrm{Hg}$ differential to blood is also apparent. An association was established between the higher intake of inorganic mercury (the most water soluble form) and the gills close contact with the dissolved and particulate metal species in water. ${ }^{45}$ Moreover, Maury-Brachet et al. ${ }^{16}$ 
demonstrated that benthivorous species absorb the metal principally in the inorganic form (48\% to $72 \%)$. Therefore, the high $\mathrm{T}-\mathrm{Hg}$ differential from gills to its internal interface (blood) gives support to the idea that gills provide a rapid and significant storage compartment for inorganic mercury. ${ }^{47}$ This aspect can assume an augmented significance if we consider the high renewal rate of branchial tissue as an unfavourable factor to bioconcentration; gills' epithelium is regularly subject to exfoliation and erosion, which is counteracted by an intense cell division rate. ${ }^{48}$

The tendency of the gills/kidney ratios to be nearer to 1 , namely at L2, associated with the significant correlation observed between $\mathrm{T}-\mathrm{Hg}$ in gills and kidney, corroborates the idea that kidney is preferentially targeted by chemicals when taken up through the gills. ${ }^{49}$ It is also well known that kidney is quite susceptible to water-borne inorganic mercury exposure. ${ }^{47}$

The role of blood in the transportation and redistribution of mercury can be better understood by analysing blood/tissue ratios, namely for internal tissues not directly involved in the absorption. Thus, it is clear that the lowest blood/tissue values were obtained for the liver and kidney $(<0.04)$, which can be regarded as an additional indication that mercury is accumulated in these organs under stable and chelated forms. The highest ratios (still <1) were found for muscle and brain (around 0.1 and 0.2 , respectively). Current measurements showed a high prevalence of organic mercury in muscle, and the same was previously demonstrated for the brain. ${ }^{50}$ In view of the elevated stability of organic mercurial deposits due to a strong affinity for thiol groups of certain proteins, ${ }^{51}$ both tissues should be regarded as end of the line for mercury distribution. Furthermore, muscle tissues have been suggested to act as a sink for methylmercury. ${ }^{52}$ Methylmercury is incorporated in fish muscle and brain tissue, most likely by forming a methylmercury-cysteine complex. ${ }^{53}$ This mechanism is particularly important in the brain since this complex mimics the behaviour of normal endogenous substrates, utilizing transport systems inherent to the blood-brain barrier (BBB) to gain access to the central nervous system (CNS). ${ }^{50}$ The similarity between blood/muscle and blood/brain ratios is a symptom of an equivalent mercury uptake in the two tissues and, subsequently, an evidence of the inefficacy of the BBB in reducing the rate of mercury transport into the CNS parenchyma.

A lack of significant differences in each tissue-to-tissue $\mathrm{T}-\mathrm{Hg}$ ratio was observed when the three stations were compared. This indicates that mercury organotropism is not markedly affected by the environmental levels or by the subsequent burden in the body.

\subsection{Suitability of L. aurata as bioindicator for mercury contamination}

L. aurata was selected in the present work because it is one of the dominant species in the surveyed lagoon (Ria de Aveiro), being easy to identify and capture in both pristine and metal-contaminated environments. ${ }^{19}$ As a benthopelagic species, its feeding behaviour (detritivore) and its life history make it particularly appropriate to the current goals. In fact, L. aurata showed the ability to detect inter-sites differences in relation to L1 and L2. This is a particularly interesting finding considering the proximity of these two sampling stations $(2 \mathrm{~km})$ and the mobility usually attributed to fish species, and invoked as a limiting factor for its application as bioindicator. Hence, the current results indicate $L$. aurata as a relatively sedentary species, making it a good candidate as a bioindicator in the context of fish species. Additionally, the adoption of juvenile specimens provides information on short-term variations of mercury concentrations in the environment, which can be compromised by using adult specimens.

\subsection{Human health implications}

The presence in fish muscle of high $\mathrm{T}-\mathrm{Hg}$, where large proportions are organometallic mercury, in combination with the fact that seafood consumption is the main source of mercury intake in people not occupationally exposed, amplifies the need for preventive measures to safeguard public health. ${ }^{13}$ The official regulatory agencies have set limits for mercury concentrations above which the fish is considered unsuitable for human consumption. The European Commission decision 93/351 established this limit at $0.5 \mu \mathrm{g} \mathrm{g}^{-1} \mathrm{w} \mathrm{wt}^{54} \mathrm{In}$ view of that, the T$\mathrm{Hg}$ measured in the current study in L. aurata muscle at Laranjo Basin should not be regarded as unsafe for consumption, as it did not exceed the previous regulatory limits.

However, the previous assumption should be regarded with some criticism, since it has been increasingly assumed that the regulatory thresholds should take into consideration the fish consumption rate of each particular population. The Portuguese population is the major seafood consumer in the EU, with

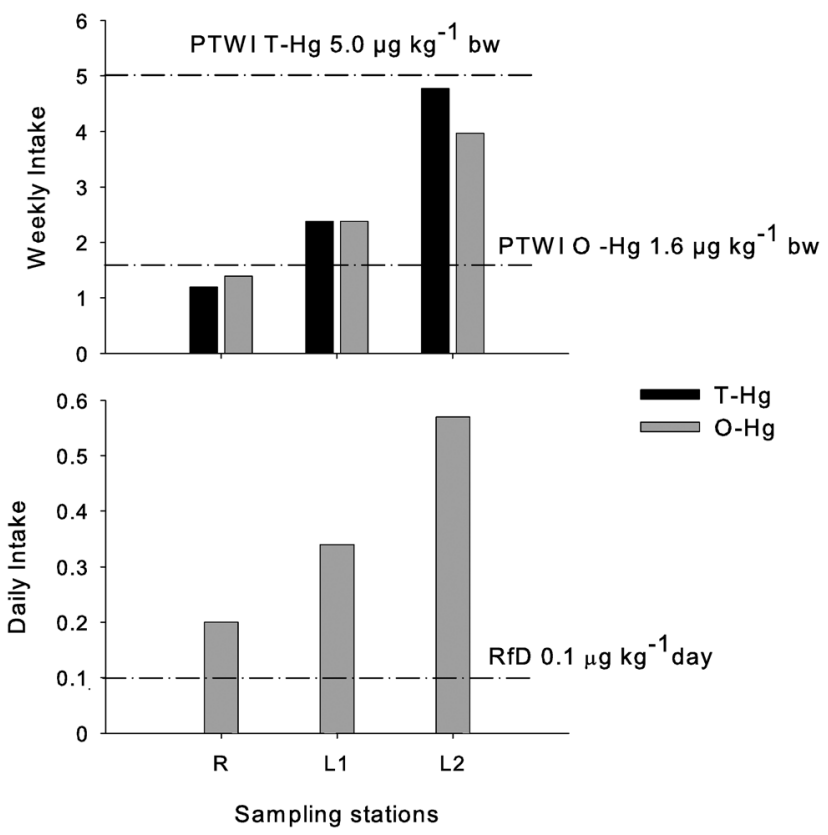

Fig. 3 The estimated weekly intake for total (T-Hg) and organic $(\mathrm{O}-$ $\mathrm{Hg}$ ) mercury and daily intake for $\mathrm{O}-\mathrm{Hg}$ (lines) in L. aurata muscle for each sampling station, compared to the WHO provisional tolerable weekly intake (PTWI) limits and EPA reference dose (RfD), respectively. Sampling stations at Ria de Aveiro are: reference (R), moderately (L1) and highly contaminated (L2) areas. PTWI values are 5.0 and $1.6 \mu \mathrm{g} \mathrm{Kg}^{-1}$ body weight (bw) for T-Hg and $\mathrm{O}-\mathrm{Hg}$ respectively. $\mathrm{RfD}$ is $0.1 \mu \mathrm{g} \mathrm{kg}^{-1}$ per day. Calculations considered $60 \mathrm{~kg}$ body weight. 
a weekly average consumption of $1192 \mathrm{~g}$ and an annual rate of 62 $\mathrm{kg}$ per person. ${ }^{55}$ Estimation of the weekly fish intake for $\mathrm{T}-\mathrm{Hg}$ and $\mathrm{O}-\mathrm{Hg}$ was calculated and compared with the provisional tolerable weekly intake (PTWI) recommended by the Joint FAO/ WHO Expert Committee on Food Additives (5.0 and $1.6 \mu \mathrm{g} \mathrm{kg}^{-1}$ body weight for $\mathrm{T}-\mathrm{Hg}$ and $\mathrm{O}-\mathrm{Hg}$, respectively). ${ }^{56}$ Calculations were done adopting the weekly fish consumption of the Portuguese population using a body weight of $60 \mathrm{~kg}$ (Fig. 3). Concerning $\mathrm{T}-\mathrm{Hg}$, the estimated weekly intake is below the established PTWI in R and L1, but in L2 reaches the advised limit. On the other hand, weekly intake estimated for $\mathrm{O}-\mathrm{Hg}$ clearly exceeds the safety PTWI limit in the contaminated stations L1 (1.5-fold) and L2 (2.5-fold). Additionally, the daily fish intake dose was calculated and compared with the EPA reference dose $\left(\mathrm{RfD}=0.1 \mu \mathrm{g} \mathrm{kg}^{-1}\right.$ per day). ${ }^{6}$ Fish from all the sampling stations were above this limit, reaching in L2 a level 6 times higher than the imposed RfD (Fig. 3).

The present results raise a question concerning the relevance of mercury quantification in kidney when the risk to humans is under analysis. Despite the substantially low mass of kidney in relation to muscle, this aspect must be carefully considered taking into account the high levels likely to be found in this organ, as well as because it is not removed by the common evisceration procedures.

\section{Conclusions}

The results of this work demonstrated that:

(i) The determination of mercury accumulation in L. aurata key tissues reflected inter-site differences, strengthening its suitability as an indicator of metal contamination. Besides the tissues commonly mentioned in the literature (liver and muscle), the brain showed a promising ability to reveal the environmental mercury contamination extent. Moreover, brain and kidney can play a relevant role in biomagnification processes in top consumers, highlighting their importance in environmental risk assessment;

(ii) The mode of mercury distribution and deposition showed to depend on the specific tissue and, thus, clear differences were observed resulting in the pattern kidney $>$ liver $>$ muscle $>$ brain $>$ gills $>$ blood. The evaluation of mercury load in a large set of tissues/organs, as well as the computation of tissue-to-tissue relations, can provide new information contributing to the knowledge of mercury organotropism;

(iii) The high mercury levels found in organs involved in vital physiological processes, namely the brain, pointed out the risk to autochthonous fish fauna;

(iv) The risk to humans can not be excluded in relation with the consumption of fish living in the Laranjo Basin; it reinforced the importance to define the regulatory thresholds taking into consideration the fish consumption rate, in order to efficiently protect against hazardous exposure.

\section{Acknowledgements}

This work was financed by the Portuguese Foundation for Science and Technology (FCT) trough a PhD grant to C. L. Mieiro (SFRH/BD/28733/2006) and CESAM-University of
Aveiro. The authors are indebted to J. P. Coelho who helped in the organic mercury determination.

\section{References}

1 L. L. Amado, C. E. da Rosa, A. M. Leite, L. Moraes, W. V. Pires, G. L. L. Pinho, C. M. G. Martins, R. B. Robaldo, L. E. M. Nery, J. M. Monserrat, A. Bianchini, P. E. Martinez and L. A. Geracitano, Mar. Poll. Bull., 2006, 52, 199-206.

2 E. Ramalhosa, P. Monterroso, S. Abreu, E. Pereira, C. Vale and A. Duarte, Wetlands Ecol. Manage., 2001, 9, 311-316.

3 G. Guzzi and C. A. M. La Porta, Toxicology, 2008, 244, 1-12.

4 A. K. Whitfield and M. Elliott, J. Fish Biol., 2002, 61(A), 229-250.

5 J. P. Shimshack, M. B. Ward and T. K. M. Beatty, J. Environ. Econ. Manage., 2007, 53, 158-179.

6 US EPA, Mercury Update: Impact on Fish Advisories, EPA-823-F-01011, EPA, Washington, 2001.

7 S. C. Jewett and L. K. Duffy, Sci. Total Environ., 2007, 387, 3-27.

8 R. Van der Oost, J. Beyer and N. P. E. Vermeulen, Environ. Toxicol. Pharmacol., 2003, 13, 57-149.

9 C. Afonso, H. M. Lourenço, A. Dias, M. L. Nunes and M. Castro, Food Chem., 2007, 101, 120-125.

10 T. Agusa, T. Kunito, A. Sudaryanto, I. Monirith, S. Kan-Atireklap, H. Iwata, A. Ismail, J. Sanguansin, M. Muchtar, T. S. Tana and S. Tanabe, Environ. Poll., 2007, 145, 766-777.

11 M. H. G. Berntssen, A. Aatland and R. D. Handy, Aquat. Toxicol., $2003, \mathbf{6 5}, 55-72$.

12 M. Mela, M. A. F. Randi, D. F. Ventura, C. E. V. Carvalho, E. Pelletier and C. A. Oliveira Ribeiro, Ecotoxicol. Environ. Saf., 2007, 68, 426-435.

13 M. M. Storelli, A. Storelli, R. Giacominelli-Stuffler and G. O. Marcotrigiano, Food Chem., 2005, 89, 295-300.

14 J. Burger and M. Gochfeld, Environ. Res., 2007, 105, 276-284.

15 J. Cizdziel, T. Hinners, C. Cross and J. Pollard, Environ. Monit., 2003, 5, 802-807.

16 R. Maury-Brachet, G. Durrieu, Y. Dominique and A. Boudou, Sci. Total Environ., 2006, 368, 262-270.

17 M. E. Pereira, A. Duarte, G. E. Millward, S. N. Abreu and C. Vale, Water Sci. Technol., 1998, 37, 125-130.

18 E. Ramalhosa, E. Pereira, C. Vale, M. Válega and A. Duarte, Mar. Poll. Bull., 2005, 50, 682-697.

19 M. Pacheco, M. A. Santos, M. Teles, M. Oliveira, J. E. Rebelo and L. Pombo, Environ. Monit. Assess., 2005, 107, 133-153.

20 A. Mucci, M. Lucotte, S. Montgomery, Y. Plourde, P. Pichet and H. V. Tra, Can. J. Fish. Aquat. Sci., 1995, 52, 2507-2517.

21 C. T. Costley, K. F. Mossop, J. R. Dean, L. M. Garden, J. Marshall and J. Carroll, Anal. Chim. Acta, 2000, 405, 179-183.

22 M. Válega, S. Abreu, P. Pato, L. Rocha, A. R. Gomes, M. E. Pereira and A. C. Duarte, Water, Air, Soil Poll., 2006, 174, 223-234.

23 J. H. Zar, Biostatistical Analysis, Prentice Hall, New Jersey, 4th edn., 1999.

24 R. Capelli, K. Das, R. De Pellegrini, G. Drava, G. Lepoint, C. Miglio, V. Minganti and R. Poggi, Sci. Total Environ., 2008, 390, 569-578.

25 P. Kotze, H. H. Preez and J. H. J. van Vuren, Water S.A., 1999, 25, 99-110.

26 Z. K. Gašpić, T. Zvonarić, N. Vrgoč, N. Odžak and A. Barić, Water Res., 2002, 36, 5023-5028.

27 M. Gochfeld, Ecotoxicol. Environ. Saf., 2003, 56, 174-179.

28 M.-H. Chen and C.-Y. Chen, Mar. Poll. Bull., 1999, 39(1-12), 239244.

29 M. H. Choi and J. J. Cech, Environ. Toxicol. Chem., 1998, 17(10), 1979-1981.

30 A. C. Elia, R. Galarini, M. I. Taticchi, A. J. M. Dörr and L. Mantilacci, Ecotoxicol. Environ. Saf., 2003, 55, 162-167.

31 V. Filipović and B. Raspor, Water Res., 2003, 37, 3253-3262.

32 M. C. Magalhães, V. Costa, G. M. Menezes, M. R. Pinho, R. S. Santos and L. R. Monteiro, Mar. Poll. Bull., 2007, 54, 16541662.

33 R. P. Mason, J. R. Reinfelder and F. M. M. Morel, Water, Air, Soil Pollut., 1996, 80, 915-921.

34 R. P. Mason, J. R. Reinfelder and F. M. M. Morel, Environ. Sci. Technol., 1996, 30, 3191-3198.

35 D. J. Spry and J. G. Wiener, Environ. Poll., 1991, 71(2-4), 243-304. 
36 K. Kannan, R. G. Smith Jr., R. F. Lee, H. L. Windom, P. T. Heitmuller, J. M. Macauley and J. K. Summers, Arch. Environ. Contam. Toxicol., 1998, 34, 109-118.

37 J. P. Coelho, M. Rosa, M. E. Pereira, A. C. Duarte and M. A. Pardal, Estuarine, Coastal Shelf Sci., 2006, 69, 629-635.

38 J. K. Schaefer, J. Yagi, J. R. Reinfelder, T. Cardona, K. M. Ellickson, S. Tel-Or and T. Barkay, Environ. Sci. Technol., 2004, 38, 4304-4311.

39 R. M. Goldstein, M. E. Brigham and J. C. Stauffer, Can. J. Fish. Aquat. Sci., 1996, 53, 244-252.

40 S. N. Abreu, E. Pereira, C. Vale and A. C. Duarte, Mar. Poll. Bull., 2000, 40(4), 293-297.

41 D. Raldúa, S. Díez, J. M. Bayona and D. Barceló, Chemosphere, 2007, 66, 1217-1225.

42 C. J. Henny, E. F. Hill, D. J. Hoffman, M. G. Spalding and R. A. Grove, Ecotoxicology, 2002, 11(4), 213-231.

43 C. Hogstrand and C. Haux, Toxicol. Appl. Pharmacol., 1990, 102, 5665.

44 S. Andres, J.-M. Laporte and R. P. Mason, Aquatic Toxicol, 2002, 56, 303-320.

45 J.-M. Laporte, S. Andres and R. P. Mason, Comp. Biochem. Physiol., 2002, C 131, 185-196.

46 S. Guilherme, M. Válega, M. E. Pereira, M. A. Santos and M. Pacheco, Mar. Poll. Bull., 2008, 56, 845-859.
47 C. A. Oliveira Ribeiro, L. Belger, É. Pelletier and C. Rouleau, Environ. Res., 2002, 90, 217-225.

48 M. Pacheco, M. A. Santos and M. A. van Der Gaag, Sci. Total Environ., 1993, 134, 817-822.

49 J. B. Pritchard and J. R. Bend, Drug Metab. Rev., 1984, 15, 655-671.

$50 \mathrm{~W}$. Zheng, M. Aschner and J. F. Ghersi-Egea, Toxicol. Appl. Pharmacol., 2003, 192, 1-11.

51 P. Bustamante, V. Lahaye, C. Durnez, C. Churlaud and F. Caurant, Sci. Total Environ., 2006, 368(2-3), 585-596.

52 J. J. Leaner and R. P. Mason, Environ. Toxicol. Chem., 2004, 23, 2138-2146.

53 H. H. Harris, I. J. Pickering and G. N. George, Science, 2003, 301, $1203-1211$.

54 Official Journal of the European Communities, L. 144 of 16 June, 1994.

55 H. M. Lourenço, C. Afonso, S. Gonçalves, M. F. Martins, I. Batista, and M. L. Nunes, in Livro de Resumos das II Jornadas "Qualidade, Inovação e Segurança dos Produtos da Pesca", INIAP/IPIMAR/ DITVPP, Lisboa, Portugal, 2006, $14 \mathrm{pp}$.

56 WHO (World Health Organization), Evaluation of certain food additives and contaminants, Sixty-seventh report of the Joint FAO/ WHO Expert Committee on Food Additives-WHO technical report series; no. 940, WHO, Rome, 2007. 